\title{
Gender Based Differences in the Productivity of Grain Legume Farmers in Benue State, Nigeria
}

\author{
Lorine Mando, C. K. Biam, P. A. Burbwa \\ Department of Agricultural Economics, Federal University of Agriculture, Makurdi, Benue \\ State
}

Received: Mar. 10, 2019

Accepted: Oct. 20, 2019

Published: Oct. 27, 2019

doi:10.5296/jas.v8i1.15716

URL: https://doi.org/10.5296/jas.v8i1.15716

\begin{abstract}
The study was carried out to assess the differences in the productivity of grain legume farmers, based on gender in Benue State, Nigeria. A Sample size of 220 grain legume farmers comprising 110 male and 110 females was used. Data were collected with the use of a well structured questionnaire. The collected data were analyzed using descriptive statistics, such as frequency, percentage and mean, as well as inferential statistics, such as t-test and total factor productivity. The results revealed that the mean age of female respondents was 38 years while that of male was 40 years. A larger proportion of the male and female respondents were married (82.7\%, and 71.8\%:, respectively). The result showed a mean household size of 7 persons for females and 8 persons for males. Also the average annual income was $\$ 218,309$ for females and $\$ 258,285$ for male grain legume farmers. Farming was seen as their major occupation with an average farming experience of 9 years for the females and 10 years for the males. An average farm size of 2.8 hectares for female respondents and 3.4 hectares for the males exists in the study area. Furthermore, result on productivity showed that the mean yield/ha of male respondents was higher (780.28) than the yield of female (696.85) respondents. The t-test result revealed that there was a significant difference in the yield of male and female grain legume farmers $(\mathrm{t}=1.968, \mathrm{P}=0.050)$, and there was also a significant difference in the productivity of male and female farmers $(\mathrm{t}=1.648, \mathrm{P}=0.041)$. The study therefore recommends that female farmers should be encouraged to acquire higher education and also female grain legume farmers should be given equal rights as regards productive factors like land.
\end{abstract}

Keywords: differences, productivity, grain legumes, gender, Benue State

\section{Introduction}

Gender inequality refers to uneven treatment or perceptions of individuals based on their gender. It arises from differences in societal constructed gender roles at the same time, 
biologically all the way through chromosomes, brain make up and hormonal differences (Wood, 2005).It is probably a key factor in producing or exacerbating a wide range of social ills such as educational disadvantage, health inequalities, intergenerational immobility, and crime, and may undermine social cohesion. It relates with economic performance but in a much more complex fashion than a simple trade-off between growth and inequality (Nolan, 2009).

It is a common knowledge that gender inequality is one of the most pervasive forms of inequality particularly because it cuts across other forms of inequality (Franklin, 2007). The significance of gender equality is highlighted by its inclusion as one of the 17 Millennium Development Goals (MDGS), that serve as a framework for halving poverty and improving lives. United Nations and the World Bank (2012) emphasize the importance of gender equality for improvement in agricultural productivity/food security, nutrition, poverty and empowerment. As an essential component of all agricultural systems, grain legumes (plants in the family fabaceae or leguminosae such as beans, pulses, oil seeds) also called pulses are grown primarily for their food grain edible seeds. These seeds are harvested matured and marketed dried to be used as food or feed and processed into various products. Grain Legumes occupy an important place in human nutrition, especially in the dietary pattern of low income groups of people in developing countries. Considered as "poor man's meat", grain legumes are protein rich and affordable foods and also vital sources of micronutrient such as iron, reducing widespread anemia caused by lack of diversity in the starch based diets of the very poor. In addition to feeding their households, many poor grain legume families derive vital income by selling part of their crop (International Institute of Tropical Agriculture, 2013). Small holders generally cannot afford to buy enough chemical nitrogen fertilizers, as a result the yields of their crops are very low.

A stellar advantage of grain legumes is their capacity to biologically convert nitrogen from the atmosphere into the soil. A second major environmental benefit is that grain legume crops diversify typical farming systems, greater diversity increases food and income security. The major grain legumes produced in Benue State include: Soyabeans, groundnut, bambaranut and cowpea. Broad efforts to enhance the productivity of grain legume farmers, and sustain the growth of the rural economy of Nigeria, are needed to enhance the resilience of Nigerian agricultural household and to lift them out of poverty, hunger and malnutrition. An increased focus on mitigating the effects of gender inequality among grain legume farmers is clearly important and has the potential of reducing poverty and food insecurity by enhancing the productivity of grain legume farmers, thereby achieving three of the Millennium Development Goals (MDGs).

Different rules, norms and values govern gender division of labor and gender distribution of resources, responsibilities agency and power. These are critical elements for understanding the nature of gender inequality in different societies. The outcomes of these pervasive gender differences include lower incomes and lower production levels among women. This leads them to grow a larger share of food crops that pay less, but guarantee at least a minimal subsistence level of food availability (Heyer, 2006; Turner et al. 1997). In addition, they tend to adopt new farming practices less frequently and are more prone to abandon them even 
after adoption (Marenya and Barrett, 2007). Studies in Asia is more sparse, but existing ones show that women farmers are as productive as male farmers or would be as productive with the same access to inputs and services (Bina, 2012).

Persistent inequality constrains a society's productivity and ultimately slows its rate of economic growth and the economy pays for this through reduced productivity or diminished national output (Awoyemi, 2004).Although women have been reported to exhibit more level of commitment and show higher efficiency in grain legume production by investing more number of man days at the farm, ownership of basic resources such as land, credit and chemicals amongst others leave them vulnerable in the hands of their male counterpart. (Yemisi et al.2009)

A lot of literatures have acknowledged gender inequality, for instance in a recent work on gender productivity differentials among smallholder farmers in Africa, Mukasa and Salami (2016) found that yields on agricultural lands managed by Nigerian, Tanzanian, and Ugandan women are systematically lower than those managed by men. Furthermore, they identified various factors explaining these gaps, ranging from differences in quantity and quality of land cultivated by farmers to differences in input uses and household characteristics.

Mtsor et al. (2014) analyzed gender inequality and women participation in agricultural development in Nigeria and concluded that systemic gender based biases or inequalities are one of the major issues limiting women from engaging in and accessing agricultural related resources, and that of Yemisi et al. (2009) who analyzed gender issues in agriculture and rural development in Nigeria and concluded that the contribution made by rural women to agricultural production and rural development is grossly underappreciated in spite of the dominant role women play in the sector.

They, therefore, deserve to be given due consideration as far as decision making process and ownership of basic assets in Agriculture is concerned but there seems to be little or no empirical work on gender effects on specific crops, nor differentiation in the productivity of men and women in the production of such crops. No known study has been done to provide empirical evidence on gender disparity in grain legume production, and the effects of such disparity on the productivity of grain legume farmers, in Benue State, therefore this research becomes imperative to fill the gap.

This study seeks to:-

1. Identify socio-economic characteristics of male and female grain legume farmers in the study area;

2. Compare the difference in the productivity of male and female grain legume farmers in the study area;

To address the problem of this research, the study was guided by the null hypothesis stated below

$\mathrm{H}_{0}$ : There is no significant difference in the productivity of male and female grain legume farmers in the study area. 


\section{Methodology}

\section{The Study Area}

The study was conducted in Benue State, located between $6^{0} 35^{\mathrm{E}} \mathrm{E}$ and $10^{\circ} \mathrm{E}$ and between latitudes $6^{0} 30^{\prime} \mathrm{N}$ and $8^{0} 10^{\prime} \mathrm{N}$ of the equator, and has a tropical climate, with temperature fluctuating between $23^{\circ} \mathrm{C}$ to $30^{\circ} \mathrm{C}$ and annual rainfall between $150 \mathrm{~mm}$ to $180 \mathrm{~mm}$. The rainy season starts from April and lasts till October, while the dry season begins from November and ends in March.

Benue State lies at the middle belt region of Nigeria with a population of 4,219, 244 people(NPC, 2006).Bounded by Nassarawa State to the North, Taraba State to the North-East, Cross River State to the South, Enugu State to the South-West, Kogi State to the West, and Republic of Cameroon to the South East (Age, 2002). The state has a land mass of 30,955 kilometers square. The State derived its name from the Benue River, which is the second largest river in the country, and the most prominent geographical feature in the State. The main occupation of the people of Benue State is farming. The main crops produced are yam, cassava, potatoes, rice, millet, sorghum, groundnut, sesame, soybeans, cowpea, fruits and vegetables. With a vast area of land the state produces a large proportion of the food of Nigeria; with about $80 \%$ of the population engaged in agriculture, which earned the State its appellation of "Food Basket of the Nation."

\section{Sampling Technique}

A sample size of 220 respondents was selected using multistage sampling techniques. In the first stage, the State was stratified into three agricultural Zones, namely Zones A, B and C. In the second stage, five Local Government Areas, where grain legumes is predominantly produced were purposively selected from the three agricultural zones, two from Zone A, two from Zone B, and one from Zone C. The Local Governments Areas that were selected include: Kwande and Vandeikya from Zone A; Makurdi and Gboko from Zone B; and Agatu from Zone $\mathrm{C}$. In the third stage, one council ward was randomly selected from each of the selected Local Government Areas. Sample frame obtained from Benue State Agricultural and Rural Development Authority (BNARDA), was stratified into male and female farmers, 110 male and 110 female farmers were randomly selected from each strata, using a sampling proportion of $5 \%$ across board which gave a total sample size of 220 respondents for the study.

\section{Data Analysis}

Data were analyzed using both descriptive and inferential statistics. Descriptive statistics like frequency distribution, mean and percentage were used. Total Factor Productivity was used to estimate the productivity of the respondents, while T-test was used to measure the difference in the productivity.

\section{Total Factor Productivity}

Total factor productivity is measured as the inverse of unit cost. This is so since it is the ratio of the output to total variable cost. The total factor productivity (TFP), was used to estimate 


\section{Macrothink}

the productivity of grain legume farmers in the study area, using the Key and Mcbride (2003) approach as follows:

$$
\begin{gathered}
\text { Average productivity }=\frac{y}{x i} \\
\text { Marginal productivity }=\frac{\partial y}{\partial x i} \\
\text { TFP }=\frac{Y}{T V C}
\end{gathered}
$$

Where;

TFP $=$ Total Factor Productivity

$\mathrm{Y}=$ Quantity of grain legume output

TVC $=$ Total Variable Cost

$$
\mathrm{TFP}=\frac{Y}{\sum P i x i} \quad(\mathrm{i}=1,2 \ldots \ldots)
$$

Where;

$P_{i}=$ Unit price of the ith variable input

$\mathrm{X}_{\mathrm{i}}$ Q Quantity of the ith variable input

This methodology ignores the Total Fixed Cost (TFC), as it does not affect the profit maximization condition, it is fixed and constant.

\section{Results and Discussion}

\section{Socio-Economic Characteristics of the Respondents}

The results in Table 1 show that majority (58.2\%) of the female respondents were within the age bracket of $21-40$ years while $48.2 \%$ of the male respondents were within the same age bracket. This indicates that more females belong to this age bracket as compared to the male grain legume farmers. Implying that more young women were involved in grain legume production than their male counterparts. Also a small proportion $(5.5 \%)$ of the female and male grain legume farmers (3.6\%) belong to the age bracket of over 61 years, with an average age of 37.8 and 39.7 years for female and male respectively. This implies that both the male and female grain legume farmers are agile, strong and energetic to actively engage in farming activities. This finding is in line with that of Adisa et al.(2013) that these age groups of farmers are regarded as the active and productive age. It also conforms to the findings of Balogun et al. (2013) that the sense of responsibility at this age is very high and they also 
have enough energy and capability to harness for effective production.

Results on marital status revealed that majority $(72.0 \%)$ of the female farmers were married while $8.4 \%$ fell in the category of divorced/separated. Also, majority $(82.7 \%)$ of the male respondents were married while $0.9 \%$ indicated they were widows. This indicates that even though majority comprising both male and female were married, the male grain legume farmers had a higher proportion of married people. The implication of majority of the males being married is that farming operations or roles on grain legume farms can be effectively distributed among members of their family, indicating that marriage makes labour supply stable for the male farmers but the females may have to hire labour which can result to an increase in their cost of production.

Result shown in Table 1 reveal that most of the female farmers (33.6\%) spent a maximum of 1-6 years in attaining primary education, while (48.2\%) of the male respondents, spent 7-12 years to attain secondary education. The average years spent in school by female farmers was 6.1 and 9.2 years for male respondents. This shows that the male respondents averagely obtained higher level of education which is secondary, than the females who obtained primary education. Indicating that the males were more educated, which makes them more knowledgeable of some agricultural practices than the females. This corresponds with the findings of Ravinder et al. (2009) who posits that in many countries, parents still prefer to send boys to school, seeing little need for sending girls. Also, Mukasa and Salami (2016) posits that it is crucial to improve women's access to better-quality education in order to widen their opportunities, improve their participation to extension services to help them increase their adoption rates of new or modern agricultural inputs, and enhance their access to credit, finance, and insurance schemes to enable them finance and secure agricultural investments.

Results on household size reveal that most $(44.5 \%)$ of the female farmers had a household size of 6-10 persons while the least percentage (16.4\%) had household size of 11-15 persons. For the male respondents, most (48.2\%) had about 6-10 persons living in the same house and eating from the same pot, followed by $30.0 \%$ with 5 persons and below in the household, $14.5 \%$ had 11-15 persons, while another minority (7.3\%) had 16 persons and above. The mean household size for this study is about 7 and 8 persons for female and male grain legume farmers respectively. This indicates that males had a larger household size as compared to the females. This finding conforms to the general practice of living together as an extended family which is common in the study area. This facilitates farm activities, and indicates availability of family labour. According to Ezihe et al. (2014) the smaller the household size, the higher the need to employ hired labour to supplement family labour thereby implying more cost.

Further results in Table 1 on annual income of respondents reveal that majority (66.4\%) of the female respondents had an annual income of $\$ 200,000$ and below, while $33.7 \%$ had annual income of 201,000 and above. On the other hand, majority (53.5\%) of the male respondents had an annual income of $\$ 201,000$ and above, while $46.5 \%$ had annual income of $\$ 200,000$ and below, with respective average annual income of $\$ 218,309$ and $\$ 258,285$ 
for female and male respondents respectively. This shows that the male respondents have higher annual income than the females, implying that males generate more finance from sale of grain legumes than their female counterparts. This could be attributed to the fact that the females incur more costs than the males and also the males have higher household size that serves as a suitable substitute for hired labour.

Years of experience as indicated by respondents reveal that for the female respondents majority $(78.2 \%)$ had a farming experience of 10 years and below, while $15.5 \%$ had an experience of 10-20 years, $4.5 \%$ have been farming for 20 years and $1.2 \%$ had over 30 years of farming experience. On the other hand, majority $(72.7 \%)$ of the male respondents had farming experience of 10 years and below, while 20.0\% had an experience of 10-20 years and $4.5 \%$ have been farming for over 30 years, with an average years of experience of 8.7 years for female respondents and 9.5 years for the male. This reveals that majority of the respondents comprising male and female had farming experience of 10 years and below but the males were more experienced than the female farmers in the study area. Also, majority of the farmers were relatively new, so they would be very keen to pay close attention to their future in terms of the crop's profitability and their own welfare. This can also be attributed to their ages as most of them were seen to be young thus had few years of farm experience. According to Ejembi et al. (2006) the length of experience is probably an indicator of a person's commitment to the profession.

The results on major occupation of the respondents show that majority $(68.2 \%)$ of the female respondents had their major occupation as farming while minority $(0.9 \%)$ were into okada riding. As regards the male respondents, majority (60.0\%) were fully engaged in farming, while artisans, traders and others had $4.6 \%, 3.6 \%$ and $0.9 \%$ respectively. The implication of this is that most of the respondents comprising male and female identified farming as their major occupation from where they derive their major source of livelihood through income generation which is used to carter for themselves and their families. However, more females were involved in farming as a major occupation as compared to the males.

Results of respondents farm size reveal that majority (50.9\%) of the female respondents had farm size of over 4 hectares, while minority $(8.2 \%)$ had 3 hectares. For the male respondents, most $(39.10 \%)$ had farm size of 4 hectares and above while the least percentage $(11.8 \%)$ had 3 hectares. The average farm size of respondents was 2.8 and 3.4 hectares for female and male respondents respectively. This implies that a large number of both the male and female grain legume farmers have farms of over 4 hectares for the cultivation of grain legumes. However, the male grain legume farmers had larger farm sizes as compared to the females. This agrees with the findings of Agwu (2004), Chukwuon and Agwu (2005), and Wiggins (2008) that most of the rural farmers in Nigeria are small scale farmers cultivating less than 10 hectares of farmland.

\section{Differences in the Productivity of Male and Female Grain Legume Farmers}

Result of the total factor productivity (TFP) in Table 2 shows the yield and productivity of male and female grain legume farmers in the study area. It was observed that the mean yield $(\mathrm{kg} / \mathrm{ha})$ of male respondents was higher (780.28) than the yield of female respondents 
(696.85). This could be attributed to the lower levels of access to education, inputs/improved technologies e.t.c. According to Emily (2015), providing female farmers globally with the same access to productive resources as male farmers (that is closing the gender gap) could increase agricultural yield by $20-30 \%$. The t-test analysis in Table 3 shows that there was a significant difference in the yield of male and female grain legume farmers $(t=1.968, \mathrm{df}=218$, $\mathrm{P}=0.050$ ). This implies that the yield obtained by male grain legume farmers is significantly higher than that of the females.

On the other hand, the productivity of male respondents was higher (25.33) than that of the female respondents (19.90). According to UN women and UNDP (2015), Plots managed by women farmers may be less productive than their male counterparts due to observable factors including inequalities in manager attributes such as experience and education, plot characteristics, agricultural technology, input use, and crop choice

Bindlish et al. (1993) found women heads of households to be less productive than men in a study in Burkina Faso, a fact that the authors attributed to cultural, religious and ethnic factors. Furthermore, the t-test result in table 3 shows that there exist a significant difference in the productivity (total factor productivity) of male and female farmers $(\mathrm{t}=1.648, \mathrm{df}=218$, $\mathrm{P}=0.041$ ). The implication of this is that the yield of male farmers is higher than that of the females and the productivity of male grain legume farmers is also higher than that of female farmers in the study area.

The outcome of this result could be attributed to lower levels of educational attainment, lower income earned from grain legume production, smaller farm size, and less access to institutional factors such as access to extension agents, access to improved technology, and access to credit as reported by the study for female grain legume farmers in the study area. This conforms to the findings of Gilbert et al. (2002); Gladwin (2002) that the main reason for women being less productive than men in relation to maize yields appears to be that women have less access to chemical input and technical know-how than men. The discriminating factors that leads to low productivity generally encompass land constraints (small land size, unequal land tenure systems and property rights), low application of modern inputs (such as chemical fertilizer, improved seeds, and pesticides), limited access to advisory and extension services, low stocks of human and physical capital and exclusion from credit and financial markets (Ali et al, 2015).Also according to FAO (2011, Women comprise a large proportion of the agricultural labor force in Sub-Saharan Africa, ranging from 30 to 80 percent yet women farmers are consistently found to be less productive than male farmers. The gender gap in agricultural productivity measured by the value of agricultural produce per unit of cultivated land ranges from 4 to 25 percent, depending on the country and the crop (World Bank 2014).

This is in contrast to the findings of Fagbemi (2000) who analyzed the productivity differences between male and female cassava/maize farmers in Oyo State and found that there was no significant difference in resource use productivity of male and female cassava/maize farmers. Based on the findings of this study, the null hypothesis which States that there is no significant difference between the productivity of male and female grain legume farmers is rejected. 


\section{Macrothink}

Journal of Agricultural Studies

ISSN 2166-0379 2020, Vol. 8, No. 1

Table 1. Socio-Economic Characteristics of Male and Female Grain Legume Farmers

\begin{tabular}{|c|c|c|c|c|}
\hline Variables & \multicolumn{2}{|c|}{ Female (110) } & Frequency & $\begin{array}{c}\text { Male(110) } \\
\text { Percentage }\end{array}$ \\
\hline \multicolumn{5}{|l|}{ Age (years) } \\
\hline$\leq 20$ & 7 & 6.3 & 7 & 6.4 \\
\hline $21-40$ & 64 & 58.2 & 53 & 48.2 \\
\hline $41-60$ & 33 & 30.0 & 46 & 41.8 \\
\hline 61 and above & 6 & 5.5 & 4 & 3.6 \\
\hline Mean & 37.8 & & 39.7 & \\
\hline \multicolumn{5}{|l|}{ Marital Status } \\
\hline Single & 11 & 10.2 & 17 & 15.5 \\
\hline Married & 79 & 72.0 & 91 & 82.7 \\
\hline Divorced/Separated & 9 & 8.4 & 1 & 0.9 \\
\hline Widowed & 11 & 9.4 & 1 & 0.9 \\
\hline \multicolumn{5}{|l|}{ Years of Education } \\
\hline$<1$ & 36 & 32.7 & 23 & 20.9 \\
\hline $1-6$ & 37 & 33.6 & 18 & 16.4 \\
\hline $7-12$ & 29 & 26.4 & 5.3 & 48.2 \\
\hline 13 and above & 8 & 7.3 & 16 & 14.5 \\
\hline Mean & 6.1 & & 9.2 & \\
\hline \multicolumn{5}{|l|}{ House-Hold Size } \\
\hline$\leq 5$ & 43 & 39.1 & 33 & 30.0 \\
\hline 6-10 & 49 & 44.5 & 53 & 48.2 \\
\hline $11-15$ & 18 & 16.4 & 16 & 14.5 \\
\hline 16 and above & 0 & 0 & 8 & 7.3 \\
\hline Mean & 6.9 & & 8.3 & \\
\hline \multicolumn{5}{|l|}{ Annual Income( $¥)$} \\
\hline$\leq 100,000$ & 52 & 47.3 & 31 & 28.2 \\
\hline $101,000-200,000$ & 21 & 19.1 & 28 & 25.3 \\
\hline 201,000-300,000 & 17 & 15.5 & 20 & 18.2 \\
\hline 301,000 and above & 20 & 18.2 & 31 & 28.3 \\
\hline \multirow{2}{*}{\multicolumn{5}{|c|}{ Years of Experience }} \\
\hline & & & & \\
\hline$\leq 10$ & 86 & 78.2 & 80 & 72.7 \\
\hline $10-20$ & 17 & 15.5 & 22 & 20.0 \\
\hline $20-30$ & 5 & 4.5 & 5 & 4.5 \\
\hline Above 30 & 2 & 1.8 & 3 & 2.8 \\
\hline Mean & 8.7 & & 9.5 & \\
\hline \multicolumn{5}{|l|}{ Occupation } \\
\hline Farming & 75 & 68.2 & 66 & 60.0 \\
\hline Trading & 22 & 20.0 & 4 & 3.6 \\
\hline Artisan & 2 & 1.8 & 5 & 4.5 \\
\hline Civil Servant & 5 & 4.5 & 20 & 18.2 \\
\hline Okada Riding & 1 & 0.9 & 6 & 5.5 \\
\hline Teaching & 5 & 4.6 & 8 & 7.3 \\
\hline Others & 0 & 0 & 1 & 0.9 \\
\hline \multicolumn{5}{|l|}{ Farm Size (ha) } \\
\hline$\leq 1$ & 17 & 15.5 & 30 & 27.3 \\
\hline 2 & 28 & 25.5 & 24 & 21.8 \\
\hline 3 & 9 & 8.2 & 13 & 11.8 \\
\hline 4 and above & 56 & 50.9 & 43 & 39.1 \\
\hline Mean & 2.8 & & 3.4 & \\
\hline
\end{tabular}


Table 2. Total Factor Productivity of Male and Female Grain Legume Farmers

\begin{tabular}{lll}
\hline Variable & Female & Male \\
& Mean & Mean \\
\hline Grain Legume yield(kg/ha) & 696.845 & 780.28 \\
Total Factor Productivity & 19.90 & 25.33 \\
$(\mathrm{Kg} / \mathrm{N})$ & & \\
\hline
\end{tabular}

Source: Field survey (2016)

Table 3. T-Test for the Productivity of Male and Female Grain Legume Farmers

\begin{tabular}{lllllllll}
\hline & Gender & No & Mean & StdDev & Std Error & t-value & Df & Sig \\
\hline Grain legume yield/ha & Male & 110 & 780.280 & 314.971 & 29.565 & & & \\
& & & & & & 1.968 & 218 & 0.050 \\
& Female & 110 & 696.843 & 307.077 & 28.813 & & & \\
Total Factor Productivity & Male & 110 & 25.333 & 34.293 & 1.899 & & & \\
& & & & & & & & \\
& Female & 110 & 19.9011 & 15.970 & 1.901 & & 218 & 0.041 \\
\hline
\end{tabular}

Source: Field Survey, (2016)

\section{Conclusion and Recommendation}

Thestudy was carried out to assess the difference in the productivity of grain legume farmers based on gender in Benue State, Nigeria, and concludes that there is a significant variation in the yield and productivity of male and female grain legume farmers, as the males are seen to have higher productivity than their female counterparts, it is further recommended that female grain legume farmers should be given equal rights to productive factors such as access to productive inputs, institutional factors, hired labour, land tenure rights and others, since they have been seen to be very productive, profitable, better utilizers of inputs and great marketers if treated fairly and unbiased.

\section{References}

Adisa, B. O., Adeokun, A. O., \& Oladoja, M. A. (2006). The effects of Socio-Economic factors of perceived adequacy on training received by women in Agriculture in Ijebu and Romo division of Ogun State, Nigeria. J. Aric. Extension, 101-109.

Agwu, A. E. (2004). Factors influencing adoption of improved cowpea technologies in Nigeria. J. Int. Agric. Ext. Educ., 11, 79-86. https://doi.org/10.5191/jiaee.2004.11109

Ali, D., Bowen, D., Deininger, K., \& Duponchel, M. (2015). Investigating the gender gap in agricultural productivity. Evidence from Uganda, Policy Research Working Paper, No.7262, The World Bank. https://doi.org/10.1596/1813-9450-7262

Awoyemi, A. (2004). Gender Inequalities and Economic Growth: New Evidence from Cassava based farm holdings in rural South-Western Nigeria Department of Agricultural Economics University of Ibadan, Ibadan, Nigeria. 
Balogun, F. O., Trumen, A. W., \& Kron, S. J. (2013). DNA resection are required for checkpoint activation in budding yeast: Journal Article/Research Support/Non U.S Govt 12(9), 751-760. https://doi.org/10.1016/j.dnarep.2013.06.003

Benue Agricultural and Rural Development Authority (BNARDA) (2005). Implementation Completion report on National Special Programme for Food Security (NSPFS), Benue State, Nigeria.

Chukwone, N. A., \& Agwu, A. E. (2005). Financing agricultural technology delivery in Nigeria: would farmers be willing to pay? Journal of Extension System, 22, 69-85.

Ejembi, E. P., Ejembi, S. A., \& Agbulu, O. N. (2006). Food chain activities of women in an agrarian community in central Nigeria:Implication for rural development. Journal of Human Ecology, 19(1), 63-67. https://doi.org/10.1080/09709274.2006.11905859

Ezihe, J. A., Oboh, V. U., \& Hyande, A. A. (2014). Loan repayment among small holder maize farmers in kanke Local Government Area of Plateau State Nigeria. Current Agricultural Research Journal, 2(1), 30-36. https://doi.org/10.12944/CARJ.2.1.04

Food and Agriculture Organization (2011). The state of food and agriculture: Women in agriculture - closing the gender gap for development. Rome, Italy: FAO. Retrieved from http://www.fao.org/docrep/ 013/i2050e/i2050e.pdf. Accessed: September 21, 2015

Franke, A. C., Laberge, G., \& Oyewole, B. D. (2008). A comparison between legume technologies and fallow, and their effects on maize and soil traits, in two distinct environments of the West African savannah. Nutrient Cycling in Agroecosystems, 117-135. https://doi.org/10.1007/s10705-008-9174-2

Franklin, O. (2007). Optimal nitrogen allocation controls tree responses to elevated CO2. New Phytol., 174, 811-822. https://doi.org/10.1111/j.1469-8137.2007.02063.x

Gilbert, R. A., Sakala, W. D., \& Benson, T. P. (2002). Gender Analysis of a Nationwide Cropping System Trail Survey in Malawi AfricanQuaterly studies,vol 6(1), Retrieved http://web/africa.uf).edu/asq/v6/v6i/99.htm

Gladwin, C. H. (2002). Gender and Soil Fertility in Africa. Introduction, African Quarterly studies,6(1), Retrieved from http://web/africa.uf).edu/asq/v6/v6i/99.html.

Goldstein, M., \& Udry, C. (2008). The profits of power: Land rights and agricultural investment in Ghana. Journal of Political Economy, 116(6), 981-1022.

https://doi.org/10.1086/595561

Key, N., \& Mcbride, W. (2003). Economic and structural relationship in the U.S. Hog production.Agriculture Economic Report. No.818 USDA-ERS, February. https://doi.org/10.2139/ssrn.758464

Kilic, T., A. Palacios-Lopez, \& Goldstein, M. (2013). Caught in a productivity trap: A distributional perspective on gender differences in Malawian agriculture, Policy Research Working Paper, No. 6381, The World Bank. https://doi.org/10.1596/1813-9450-6381 


\section{Macrothink}

Journal of Agricultural Studies

ISSN 2166-0379

2020, Vol. 8, No. 1

Merenya, P. P., \& Berrett, C. (2007). Household-level determinants of adoption of improved natural resources management and practices among small holder farmers in Western Kenya. Food Policy, 32(4), 515-536. https://doi.org/10.1016/j.foodpol.2006.10.002

Mukasa, A. N., \& Salami, A. O. (2016). Gender productivity differentials among Smallholder farmers in Africa: A cross country comparison, Working Paper Series No.231, African Development Bank, Abidjan, Cote d'Ivoire.

Nolan, B. (2009). Inequality and Public Policy UCD School of Applied and Social Science Working paper Series, 9-11.

Obinne, C. P. (1991). Culture of poverty: Implication of Nigerians Socio-Economic transformation, Journal of Extension System, 7.

Ravinder, K. K., Harminder, P. S., Sunil, M., \& Shalinder, K. (2009). Characterization and Antioxidant activity of essential oils from fresh and decaying leaves of Eucalyptus terticornis.Department of Environment and vocational studies. J. Agric. Food Chem., 57(15), 6926-6966. https://doi.org/10.1021/jf9012407

UN Women, UNDP, UNEP and World Bank Group (2015). The cost of the gender gap in Productivity in Malawi, Tanzania and Uganda.

United States Agency for International Development (USDA) (1984). African Buereau of Agricultural Strategy/Education strategy paper/Washington DC

Wood, J. (2005). Gendered lives, $6^{\text {th }}$ Balmont, Wadsworth/Thomas Learning World Bank, (2007).Gender and Economic growth in Kenya. Washington, DC: World Bank for IITA 1998.

World Bank and ONE. (2014). Levelling the Field: Improving Opportunities for Women Farmers in Africa. Washington, DC: World Bank.

Yemisi, G., Mtsor, A., \& AndIdisi, D. (2010). Gender Inequality and Women Participation in Agricultural Development In Nigeria. Faculty of Agriculture, University of Abuja, Nigeria.Merit Journal of Education and Review, 2(11), 269-301.

Yemisi, I. O., \& Aisha, A. I. (2009). Gender issues in Agriculture and Rural Development in Nigeria: The Role of Women.

\section{Copyright Disclaimer}

Copyright for this article is retained by the author(s), with first publication rights granted to the journal.

This is an open-access article distributed under the terms and conditions of the Creative Commons Attribution license (http://creativecommons.org/licenses/by/4.0/). 